\title{
KEMAMPUAN MADU HITAM DALAM MENGHAMBAT PERTUMBUHAN BAKTERI Pseudomonas aeruginosa
}

\author{
Romi Syawalludin ${ }^{1}$
}

${ }^{1}$ Rumah Sakit Haji Kamino, Way Kanan

\begin{abstract}
The ability of Black Honey to Inhibits Growth of Bacteria Pseudomonas aeruginosa. The bacteria Pseudomonas aeruginosa is a microorganism that commonly cause infections nosocomial, which like infection of the wound after surgery, bacteremia, endocarditis bacterial, sinusitis, infections systems respiration and tract urinary. At this time infection by the bacteria Pseudomonas aeruginosa isbecoming increasingly difficult to overcome, because of the emergence of Pseudomonas aeruginosa resistance to antibiotics. Study retrospective of the data installation microbiology clinic in RS Dr.Soetomo, from 2009-2010 occurred an increase of bacteria Pseudomonas aeruginosa against antibiotics from surgical patients at Dr. Soetomo Hospital. One of the ways to prevent strains of bacteria that are resistant to antibiotics is needed antimicrobial alternatives that can kill the bacteria Pseudomonas aeruginosa, one of them is black honey. Activity antibacterial in honey is influenced by hydrogen peroxide, flavonoids, essential oil. Character of the antibacterial is also influenced by the effect of osmolarity are high, water low activity, the $\mathrm{pH}$ low. This study aims to determine the ability of black honey to inhibit the growth of Pseudomonas aeruginosa bacteria, also to find out the concentration of black honey that can inhibit the growth of Pseudomonas aeruginosa bacteria. Type of research this is an experiment in the laboratory (in vitro), where honey black as a variable independent, while the variable dependent is the growth of the bacteria Pseudomonas aeruginosa. Analysis of data bivariate was Anova test. Results of the study found that honey black at a concentration of $10 \%$ up to $100 \%$ can inhibit the growth of bacteria Pseudomonas aeruginosa. The concentration of $80 \%$ hpney black is quite good in its ability to inhibit the growth of the bacteria Pseudomonas aeruginosa .
\end{abstract}

\section{Keywords: Honey black, Pseudomonasaeruginos}

Abstrak: Kemampuan Madu Hitam dalam MenghambatPertumbuhan
BakteriPseudomonas aeruginosa. Bakteri Pseudomonas aeruginosa merupakan mikroorganisme yang sering menyebabkan infeksi nosokomial, yaitu berupa infeksi luka pasca operasi, bakteremia, endokarditis bakterial, sinusitis, infeksi sistim respirasi dan saluran kemih. Saat ini infeksi oleh bakteri Pseudomonas aeruginosa menjadi semakin sulit untuk diatasi, karena timbulnya resistensi Pseudomonas aeruginosa terhadap antibiotik. Studi retrospektif dari data instalasi mikrobiologi klinik di RS Dr.Soetomo, tahun 2009-2010 terjadi peningkatan bakteri Pseudomonas aeruginosa terhadap antibiotik dari pasien bedah di RS Dr.Soetomo. Salah satu cara dalammencegah strain bakteri yang resisten terhadap antibiotik, diperlukanantimikroba alternatif yang dapat membunuh bakteri Pseudomonas aeruginosa, salah satunya madu hitam. Aktifitas antibakteri pada madu dipengaruhi oleh hidrogen peroksida, senyawa flavonoid, minyak atsiri. Sifat antibakteri juga dipengaruhi oleh efek osmolaritas yang tinggi, aktivitas air rendah, $\mathrm{pH}$ yang rendah. Penelitian ini bertujuan untuk mengetahui kemampuan madu hitam dalam menghambat pertumbuhan bakteri Pseudomonas aeruginosa, juga mengetahui konsentrasi madu hitam yang mampu menghambat pertumbuhan bakteri Pseudomonas aeruginosa.Jenis 
penelitian ini adalah eksperimen di laboratorium (invitro), dimana madu hitam sebagai variable bebas, sedangkan variable terikat adalah pertumbuhan bakteri Pseudomonas aeruginosa. Analisa data bivariat yaitu uji Anova. Hasil penelitian didapatkan bahwa madu hitam pada konsentrasi $10 \%$ sampai dengan $100 \%$ dapat menghambat pertumbuhan bakteri Pseudomonas aeruginosa. Konsentrasi madu hitam $80 \%$ cukup baik kemampuannya dalam menghambat pertumbuhan bakteri Pseudomonas aeruginosa.

\section{Kata Kunci: Madu hitam, Pseudomonas aeruginos}

\section{PENDAHULUAN}

\begin{tabular}{llr}
\multicolumn{2}{c}{ Bakteri } & \multicolumn{2}{c}{ Pseudomonas } \\
aeruginosa merupakan mikro- \\
organisme yang sering
\end{tabular}
menyebabkan infeksi nosokomial. Bakteri ini sering menyebabkan infeksi luka pasca operasi, bakteremia, endokarditis bakterial, sinusitis, infeksi sistim respirasi dan saluran kemih (Jawet dkk, 2010).

Pseudomonas aeruginosa merupakan golongan bakteri oportunistik. Pasien dengan luka bakar yang luas, kistik fibrosis,leukemia akut dan transplantasi organ sering terinfeksi bakteri ini.Infeksi oleh bakteri Pseudomonas aeruginosa di rumah sakit merupakan masalah yang serius, karena angka kematian infeksi bakteri ini mencapai 50\% (Todar, 2012).

Pasien dengan penurunan jumlah neutrofil dapat terjadi infeksi invasif. Pasien bedah memiliki risiko yang lebih tinggi terjadi kasus infeksi bakteri Pseudomonas aeruginosa, karena adanya lesi kulit, tingkat imunitas yang rendah, trasmisi nosokomial dan pemberian antibiotik luas dalam jangka waktu yang lama. Saat ini infeksi Pseudomonas aeruginosa menjadi semakin sulit untuk diatasi, karena timbulnya resistensi terhadap antibiotik (Budi Priyo.P, 2010).

Studi retrospektif dari data instalasi mikrobiologi klinik di RS Dr.Soetomo periode Januari - Juni 2009 dan Januari -Juni 2010, didapatkan peningkatan infeksi Pseudomonas aeruginosa pada pasien bedah, dimana tahun 2009 infeksi pasien bedah yang disebabkan oleh Pseudomonas aeruginosa merupakan urutanke tiga sesudah Echerichia coli dan Klepsiella pneumoniae, namun pada tahun 2010 menempati urutan pertama. Pseudomonas aeruginosa paling banyak didapatkan dari spesimen pus. Tahun 2009-2010 terjadi peningkatan resistensi antibiotik pada bakteri Pseudomonas aeruginosa dari pasien bedah di RS Dr.Soetomo (Budi Priyo.P, 2010). Salah satu cara dalam menanggulangi resistensi dan mencegah strain resisten diperlukan anti mikroba alternatif, yang dapat membunuh bakteri Pseudomonas aeruginosa penyebab infeksi nosokomial, seperti infeksi luka operasi, infeksi saluran kemih dll. Pemanfaatan tanaman, sebagai obat alternatif dalam menanggulangi infeksi sampai sekarang masih berlangsung dan jenis tanaman yang dapat dipakai sebagai obat tradisional ternyata amat banyak macamnya, dimana pemanfaatannya secara umum masih berdasarkan pengalaman yang turun-temurun dari nenek moyang. Upaya penelitian masih sangat dibutuhkan untuk memberikan informasi bagi masyarakat tentang obat tradisional Indonesia, dalam rangka pengembangannya maupun pemanfaatan obat itu sendiri (Darsono dan Stephanie, 2003).

Hasil penelitian Sumarno dkk (2010), tentang uji efektifitas ekstrak daun binahong (Anredera 
cordifolia Ten.Stennis) sebagai anti mikroba terhadap Pseudomonas aeruginosa secara in vitro, didapatkan hasil, bahwa ekstrak daun binahong efektif dalam membunuh bakteri Pseudomonas aeruginosa, namun hasil penelitian Akmala N (2009), bahwa ekstrak daun katu (Sauropus androgunus) sampai dengan konsentrasi $50 \%$ dengan waktu kontak 6 jam belum dapat menghambat pertumbuhan bakteri Pseudomonas aeruginosa.

Selain dari tanaman, ada juga bahan alam yang berasal dari hewan yaitu madu yang dihasilkan oleh lebah madu nektar tanaman yang diproses oleh lebah menjadi madu dan tersimpan dalam sel-sel sarang lebah. Nektar atau sari bunga adalah cairan manis kaya gula yang diproduksi bunga dari tumbuh-tumbuhan sewaktu mekar untuk menarik kedatangan hewan penyerbuk seperti serangga (Mulu, 2004 dalam Lela, 2010).

Kemampuan madu sebagai zat antibakteri tidak terlepas dari kandungan zat aktif yang ada didalmnya. Menurut beberapa penelitian yang telah dilakukan aktifitas antibakteri pada madu dipengaruhi oleh hydrogen peroksida, senyawa flavonoid, minyak atsiri dan berbagai senyawa organik lainnya. Sifat antibakteri juga dipengaruhi oleh efek osmolaritas yang tinggi, aktivitas air rendah, $\mathrm{pH}$ yang rendah sehingga tingkat keasaman madu yang menjadi tinggi (Puspitasari, 2007). Sumber nektar yang berbeda akan mempengaruhi sifat madu yang dihasilkan oleh lebah, diantaranya dari segi warna, rasa, dan komponen madu (Suranto, 2007).

Peneliti dari Turki (Mercan, 2007), menguji kemampuan antibakteri dan anti jamur pada madu yang berasal dari daerah yang berbeda di Turki. Bakteri yang diujikan adalah Bacillus cereus, Staphylococcus aureus, Pseudomonas aeruginosa,
Klebsiella pneumoniae, Morganella morgani, Micrococcus luteus, dan E.coli sedangkan jamur yang diuji adalah Candida albicans. Madu yang berasal dari provinsi Izmir yang kaya dengan bunga tanaman Amaranthaceae, Cyperaceae dan jagung, lebih efektif menghambat bakteri $P$. aeruginosa, E.coli dan S.aureus. Penelitian lebih lanjut mengenai efektifitas madu Indonesia perlu dilakukan, termasuk manfaatnya sebagai zat antibakteri terhadap bakteri Gram Positif dan Gram Negatif.

Hasil penelitian Silvia M (2011) menunjukkan bahwa konsentrasi madu yang efektif menghambat pertumbuhan bakteri Staphylococcus aureus penyebab infeksi kulit adalah $70 \%$ dengan rata-rata zona hambat $30 \mathrm{~mm}$, dibandingkan dengan diameter sensitifitas antibiotik Ampicilin 10 mcg yaitu $29 \mathrm{~mm}$, sedangkan menurut Yolandari, FG, (2011) daya hambat madu sonokeling terhadap bakteri Escherichia coli ETEC sebesar 24,66 $\mathrm{mm}$ pada konsentrasi $100 \%$.

Hasil penelitian Huda M (2012) menunjukkan bahwa madu hutan Musi Rawas dapat menghambat pertumbuhan bakteri Escherichia coli dan bakteri Staphylococcus aureus, konsentrasi madu Hutan Musi Rawas 70\% sudah efektif dalam menghambat pertumbuhan bakteri Escherichia coli dan bakteri Staphylococcus aureus.

Sementara penelitian tentang madu hitam belum dilakukan. Madu hitam merupakan madu asli yang berasal dari nektar bunga pohon karet, singkong, kaliandra, paitan, pelawan atau lengkeng, mahoni akan menghasilkan madu yang bewarna hitam.

Berdasarkan latar belakang di atas maka penulis ingin melakukan penelitian tentang "KemampuanMadu Hitam dalam 
MenghambatPertumbuhanBakteri

Pseudomonas aeruginosa "

\section{METODE}

Jenis penelitian eksperimen di laboratorium (invitro) dengan menggunakan metode difusi agar cara Kirby-Bauer, variabel bebas adalah madu hitam, sedangkan variabel terikat yaitu pertumbuhan bakteri Pseudomonas aeruginosa. Rancangan penelitian Rancangan Acak Lengkap, artinya bakteri Pseudomonas aeruginosa yang diberi perlakuan madu hitam, yang tidak diberi perlakuan (kontrol), letaknya diacak dengan cara diundi dalam inkubator waktu diinkubasi.

Subjek penelitian adalah madu hitam yang dijual pada Rumah Madu di Bandar Lampung, lalu diencerkan dengan akuadrs steril menjadi konsetrasi $10 \%$, $20 \%, 30 \%, 40 \%, 50 \%, 60 \%, 70 \%$, $80 \%$ dan $90 \%$, masing-masing konsentrasi diulang 3 kali.

Penelitian dilaksanakan di Laboratorium Bakteriologi Jurusan Analis Kesehatan Poltekkes Kemenkes Tanjungkarang pada bulan Juni-Juli 2014.

Pembuatan suspensi bakteri dilakukan dengan cara mengambil biakan murni Pseudomonas aeruginosa, kemudian dibiakkan dalam media Nutrient Agar lalu diinkubasi pada suhu $37^{\circ} \mathrm{C}$ selama 24 jam, setelah itu diambil beberapa koloni kuman Pseudomonas aeruginosa dan dimasukkan ke dalam tabung reaksi yang berisi Nutrient Broth dengan menggunakan ose, lalu dihomogenkan perlahan, diinkubasi suhu $37^{\circ} \mathrm{C}$ selama 4 jam, bila suspensi tersebut lebih keruh dari standart Mac Farland maka ditambah $\mathrm{NaCl} 0,85 \%$, sampai kekeruhan antara suspensi bakteri dan Mac Farland setara

a. Lidi kapas steril dicelupkan ke dalam suspensi bakteri yang sudah distandarisasi kekeruhannya. b. Lidi kapas diangkat dan diperas dengan menekankan pada dinding tabung bagian dalam sambil diputar-putar.

c. Lidi kapas tersebut dipulaskan pada permukaan MHA (Muller Hinton Agar) sampai seluruh permukaan media MHA tertutup oleh suspense bakteri Pseudomonas aeruginosa. Media MHA (Muller Hinton Agar) dibiarkan selama 15 menit supaya suspensi bakteri meresap ke dalam media agar.

d. Disk direndam dalam ekstrak daun saga dan madu hitam konsentrasi $10 \%, 20 \%, 30 \%$, $40 \%$, 50\%, 60\%, 70\%, $80 \%$, $90 \%$, dan $100 \%$, lalu diletakkan pada media yang sudah dipulas dengan suspense bakteri Pseudomonas aeruginosa, dengan cara ditekan satu persatu supaya disk menempel dengan baik pada media. Jarak antara disk satu dan lainnya tidak kurang dari $15 \mathrm{~mm}$. Media MHA (Muller Hinton Agar) yang telah ditempeli disk diinkubasi suhu $37^{\circ} \mathrm{C}$ selama 24 jam.

e. Diameter zona hambat pada media MHA (Muller Hinton Agar) diukur dari ujung yang satu ke ujung yang lain melalui tengah tengah diskdengan menggunakan jangka sorong.

f. Kontrol negatif dilakukan dengan merendam disk dengan akuades, sedangkan control positif memakai antibiotik amikacin $30 \mu \mathrm{g}$ dalam bentuk disk.

Diameter zona hambat diukur dalam satuan mili meter dan Analisa data univariat yaitu menghitung rata-rata daya hambat madu terhadap pertumbuhan bakteri Pseudomonas aeruginosa, bivariat dengan Uji Anova.

\section{HASIL}

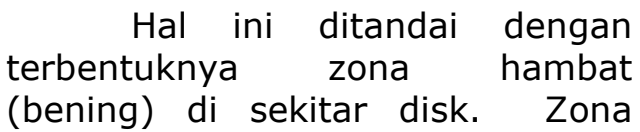


hambat ini diukur diameternya

dalam satuan mili meter (Tabel 1 ).

Tabel 1. Diameter zona hambat madu hitam terhadap pertumbuhan bakteri Pseudomonas aeruginosa

\begin{tabular}{|c|c|c|c|c|c|}
\hline \multirow[t]{2}{*}{$\begin{array}{l}\text { Konsentrasi } \\
\text { madu hitam } \\
(\%)\end{array}$} & \multicolumn{3}{|c|}{$\begin{array}{c}\text { Diameter zona hambat madu hitam } \\
\text { terhadap bakteri Pseudomonas } \\
\text { aeruginosa pada masing - masing } \\
\text { pengulangan ( } \mathrm{mm})\end{array}$} & \multirow[t]{2}{*}{$\begin{array}{c}\text { Jumlah } \\
\text { (mm) }\end{array}$} & \multirow[t]{2}{*}{$\begin{array}{l}\text { Rata- } \\
\text { rata( } \\
\mathbf{m m})\end{array}$} \\
\hline & I & II & III & & \\
\hline 10 & 7,1 & 7,1 & 7,3 & 21,5 & 7,1 \\
\hline 20 & 7,1 & 7,4 & 7,8 & 22,3 & 7,4 \\
\hline 30 & 7,4 & 8 & 8,1 & 23,5 & 7,8 \\
\hline 40 & 7,7 & 9,2 & 8,7 & 25,6 & 8,5 \\
\hline 50 & 8,4 & 9,5 & 9 & 26,9 & 8,9 \\
\hline 60 & 9,6 & 10 & 9,8 & 29,4 & 9,8 \\
\hline 70 & 9,2 & 10,5 & 9,7 & 29,4 & 9,8 \\
\hline 80 & 9,1 & 11 & 10,8 & 30,9 & 10,3 \\
\hline 90 & 11,7 & 11,3 & 11,9 & 34,9 & 11,6 \\
\hline 100 & 11,9 & 11,9 & 11,6 & 35,4 & 11,8 \\
\hline
\end{tabular}

Keterangan: diameter zona hambat termasuk diameter dari disk

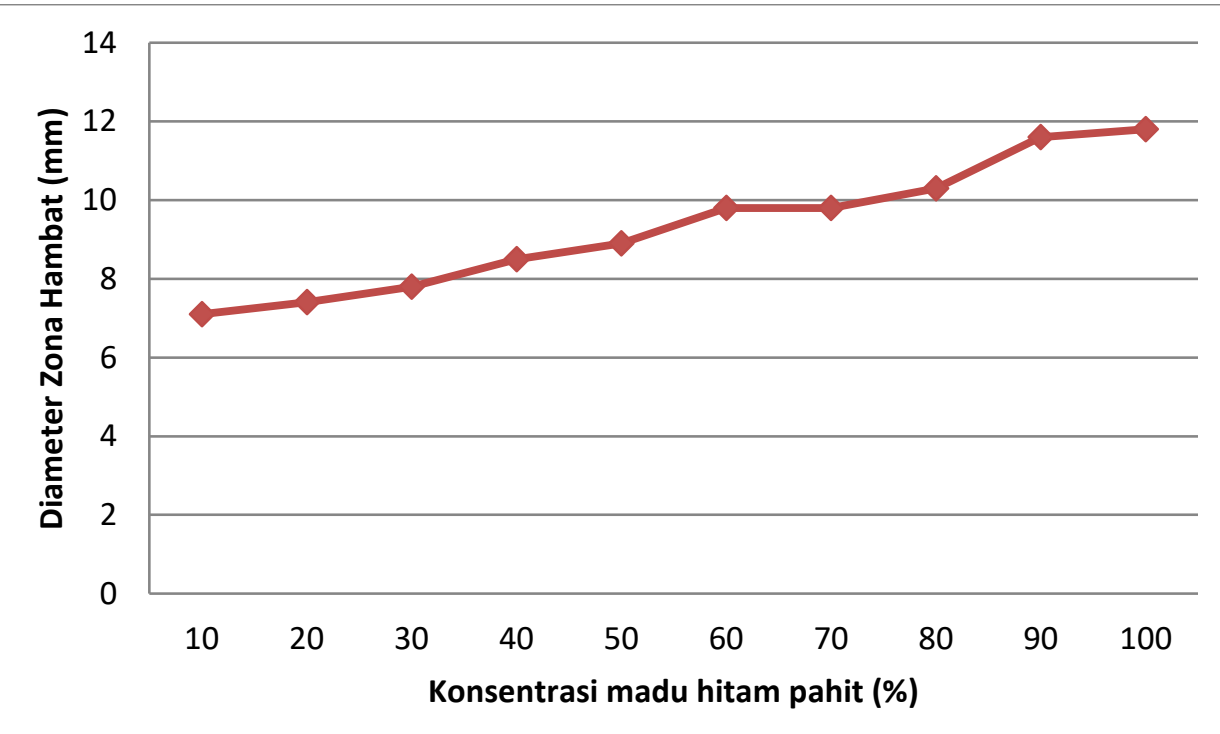

Gambar 1. Grafik pertumbuhan bakteri Pseudomonas aeruginosa setelahdiberi madu hitam

Tabel 1 dan Gambar 1 memperlihatakan bahwa, makin tinggi konsentrasi madu hitam, maka makin besar kemampuannya dalam menghambat pertumbuhan bakteri Pseudomonas aeruginosa. Setelah dianalisa data diameter zona hambat madu hitam terhadap pertumbuhan bakteri Pseudomonas aeruginosa dengan uji Anova, didapatkan bahwa $\mathrm{F}$ hitung $>\mathrm{F}$ tabel, artinya madu hitam dapat menhhambat pertumbuhan bakteri Pseudomonas aeruginosa, kemudian dilanjutkan dengan uji BNT, didapatkan bahwa konsentrasi madu hitam $10 \% \mathrm{~s} / \mathrm{d}$ $40 \%$ tidak berbeda nyata 
kemampuannyadalam

menghambat pertumbuhan bakteri Pseudomonas aeruginosa. Namun berbeda nyata dengan konsentrasi $50 \%$ sampai dengan $100 \%$. Madu hitam dengankonsentrasi $80 \% \mathrm{~s} / \mathrm{d}$ $100 \%$ tidak berbeda nyata kemampuannya dalam menghambat pertumbuhan bakteri Pseudomonas aeruginosa.

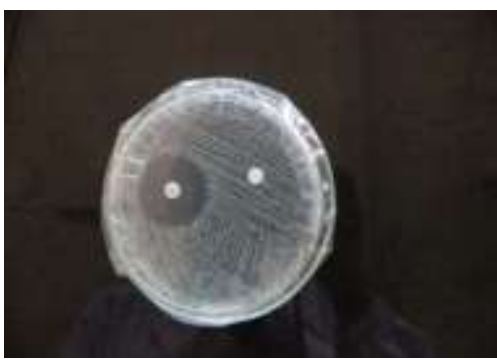

Gambar 2. Kontrol positif dan negatif
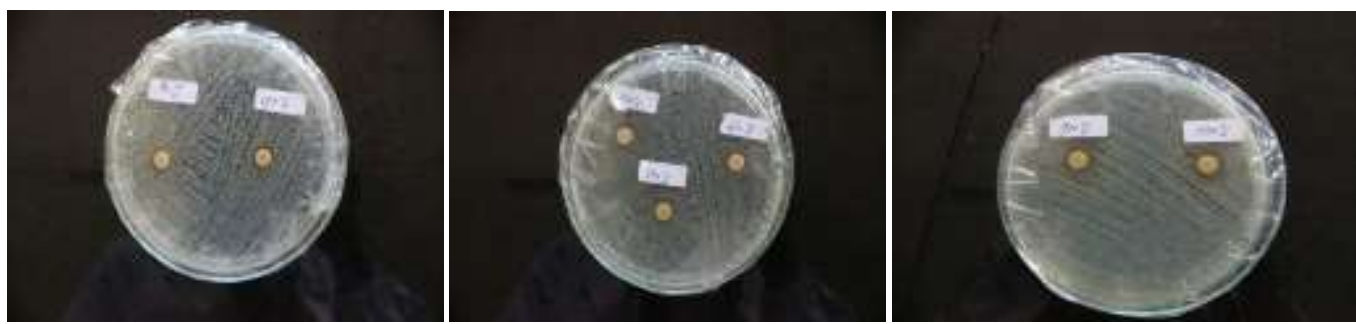

Gambar 3. Daya hambat madu hitam pahit terhadap pertumbuhanbakteri Pseudomonas aeruginosa

\section{PEMBAHASAN}

Kemampuan madu hitan dalam manghambat pertumbuhan bakteri disebabkan oleh beberapa faktor antara lain hidrogen peroksida $\left(\mathrm{H}_{2} \mathrm{O}_{2}\right)$, keasaman $(\mathrm{pH})$, tekanan osmotik. Adapun mekanisme hydrogen peroksida dalam menghambat pertumbuhan bakteri yaitu, dengan mendenaturasi protein dan menghambat sintesis atau fungsi dari asam nukleat bakteri (Molan, 1992). Sifat keasaman madu yang tinggi atau $\mathrm{pH}$ yang rendah yaitu antara 3,2-4,5 mampu menghambat pertumbuhan bakteri, karena $\mathrm{pH}$ obtimum untuk bakteri pathogen dapat berkembantg biak adalah antara $\mathrm{pH}$ 7,2-7,4, pH minimumdari bakteri Pseudomonas aeruginosa untuk dapat bertahan hidup adalah 5,6. Nilai $\mathrm{pH}$ yang rendah akan mengganggu ikatan ion dalam sel bakteri, sehingga mengganggu transpor nutrien dan mengganggu pembaharuan energy pada sel bakteri, hal ini menyebabkan terhambatnya pertumbuhan bakteri, sehingga bakteri akan mati (Suranto, 2007). Efek osmotik merupakan aktifitas antibakteri dari madu. Interaksi yang kuat antara molekul gula dengan molekul air, meninggalkan molekul air yang sangat sedikit yang tersedia bagi bakteri, semua kegiatan dalam sel bakteri membutuhkan air, sedangkan air terikat/terkristalisasi dalam larutan gula yang terdapat pada madu, sehingga air tersebut tidak dapat digunakan oleh bakteri, dan semua aktifitas dalam sel bakteri akan terganggu, maka bakteri akan kehilangan kemampuan untuk hidup, atau pertumbuhan bakteri akan terhambat (Ray, 1996). Hal ini sejalan dengan hasil penelitian 
Huda M (2012) menunjukkan bahwa, madu hutan Musi Rawas dapat menghambat pertumbuhan bakteri Escherichia coli dan bakteri Staphylococcus aureus, konsentrasi madu Hutan Musi Rawas 70\% sudah efektif dalam menghambat pertumbuhan bakteri Escherichia coli dan bakteri Staphylococcus aureus.

Madu hitam memilliki aktifitas antibakteri yang cukup baik terhadap bakteri Pseudomonas aeruginosa dimana madu hitam konsentrasi $80 \%$ setara dengan konsentrasi $90 \%$ dan $100 \%$ kemampuannya dalam menghambat pertumbuhan bakteri Pseudomonas aeruginosa. Madu hitam juga mengandung berbagai senyawa organik yang bersifat antibakteri, yang telah teridentifikasi adalah polyphenol, flavonoid, dan glikosida dan saponin yang berasal dari nektah bunga mahoni.

Madu hitam yang semakin kental maka kandungan gulanya juga semakin tinggi, sehingga agak sulit berdifusi ke dalam media perbenihan, maka antibakteri yang terdapat dalam madu hitam yang ikut terdifu dalam media perbenihan tidak begitu jauh jaraknya dengan disk yang mengandung madu hitam. Hal ini mengakibatkan diameter zona hambatan yang terbentuk tidak begitu lebar, yaitu antara $8,9 \mathrm{~mm}$ sampai $11,8 \mathrm{~mm}$ pada konsentrasi $50 \%$ sampai dengan $100 \%$

\section{KESIMPULAN}

1. Konsentrasi madu hitam $10 \%$ $\mathrm{s} / \mathrm{d} \quad 100 \% \quad$ mampu menghambat pertumbuhan bakteri Pseudomonas aeruginosa.

2. Madu hitam konsentrasi $80 \%$ sudah cukup baik kemampuanya dalam menghambat pertumbuhan bakteri Pseudomonas aeruginosa dibandingkan

\section{SARAN}

1.Perlu dilakukan penelitian yang sama menggunakan hewan percobaan (invivo).

2. Perlu dilakukan penelitian yang sama dengan metode yang lain seperti metode sumuran.

\section{DAFTAR PUSTAKA}

Agoes, H.A. (2010). Tanaman Obat Indonesia. Jakarta: Salemba Medika.

Akmala, N.(2009). Daya Hambat Ekstrak Daun Katu

(Sauropus androgunus)terhadap pertumbuhanPseudomonas aeruginosa Secara Invitro. Semarang: Universitas Muhammadiyah.

Ardhi. (2010). Lebah Madu (Apis melifera) dan Proses Pembuatan Madu.Diakses Juni 2014, dari kiathidupsehat.com/lebahmadu-apis-melifera-danproses-pembentukan-madu.

Badan POM RI. (2006). Monografi Ekstrak Tumbuhan Obat Indonesia Volume 2. Indonesia: Badan POM RI.

Brudzynski, K. (2006). Effect of hydrogen peroxide on antibacterial activities of Canadian honey. Canadian Journal of Microbiology.

Budi, P.P. (2010). Waspada Peningkatan Resistensi Antibiotik padaPseudomonas aeruginosa. Surabaya: SMF Mikrobiologi Klinik RS Dr.Soetomo.

Dalimartha, S. (2008). Atlas Tumbuhan Obat Indonesia Jilid 5. Jakarta: Pustaka Bunda.

Darsono, Farida L., Stephanie D.A.(2003).Aktivitas

Antimikroba Ekstrak Daun Jambu Biji dari Beberapa Kultivar terhadap Staphylococcus aureus ATCC 25923 dengan "HolePlate Diffusion 
Method".Jurnal Berkala

Penelitian Hayati, Fakultas

Farmasi Universitas Katolik

Widya Mandala, Surabaya.

Dalimartha, S. (2008). Atlas Tumbuhan Obat Indonesia Jilid 5. Jakarta: Pustaka Bunda.

Dewi, Mita K., Evie R., Guntur T.(2014). Aktivitas Antibakteri Ekstrak Daun Majapahit (Crescentia cujete) terhadap Pertumbuhan Bakteri Ralstonia solanacearum Penyebab Penyakit Layu.Jurnal LenteraBio, Fakultas MIPA Universitas Negeri Surabaya.

Gunawan, D., Sri M. (2004). Ilmu Obat Alam (Farmakognosi) Jilid 1. Jakarta: Penebar Swadaya. 1-140.

Hamad, S. (2007). Terapi Madu.Jakarta: Pustaka Imam.

Hanafiah, K.A. (2005). Rancangan Percobaan Teori \& Aplikasi. Jakarta: PT. Raja Grafindo Persada.

Hanani, E. (1994).Uji Daya Antibakteri Ekstrak Etanol dan Infus Daun Saga terhadap Beberapa Kuman Penyebab Penyakit Tenggorokan. Prosiding Simposium Penelitian Bahan Obat Alami VIII, Fakultas MIPA Universitas Indonesia, Jakarta.

Hidayat, Syamsul, Sri W. (2009). Seri Tumbuhan Obat Berpotensi Hias. Jakarta: PT Elex Media KomputIndo.

Huda, M.(2012). Pengaruh Madu terhadap Pertumbuhan Bakteri Gram positif (Staphylococcus aureus)dan Bakteri Gram Negatif(Echerichia coli). JurnalJurusan Analis Kesehatan Poltekkes Kemenkes Tanjungkarang.
Jawetz et al.(2010). Mikrobioloi Kedokteran Edisi 23. Jakarta: EGC.

Karsinah, H., et al.(2009). Buku Ajar Mikrobiologi Kedokteran Edisi Revisi. Jakarta: Binarupa Aksara.

Katno. (2008). Pengelolaan Pasca Panen Tanaman Obat. Balai Besar Penelitian dan Pengembangan Tanaman Obat dan Obat Tradisional Badan Litbangkes Depkes RI.

Lela, F.H. (2010). Aktivitas Antibakteri Berbagai Jenis Madu Terhadap Mikroba Pembusuk.

Surakarta:Fakultas

Pertanian Universitas

Sebelas Maret.

Mercan, N., Wilson, M, Robbinson, LM. (2007). Antimicrobial activity and pollen composition of honey samples collected from different province in Turkey. Natural Product Reseach.

McDonell, G and Russell A. (1999). Antiseptics and disinfectants: Activity, action, and resistence. United Kingdom:Welsh School of pharmacy, Cardiff University.

Molan P.C. (1992). The Antibacterial activity of honey. Bee World

Parubak, A.S.(2013). Senyawa Flavonoid yang Bersifat Antibakteri dari Akway (Drimys becariana.Gibbs).Jurnal Chemistry of Proggres, 6(1).

Permatasari, G.A., I Nengah K.B., Hapsari M.Daya Hambat Perasan Daun Sirsak Terhadap Pertumbuhan Bakteri Escherichia coli.Indonesia Medicus Veterinus.

Puspitasari, I. (2007). Rahasia Sehat Madu. Yogyakarta: B First. 
Ray,B. (1996). Fundamental Food Microbiologi. New York: CRC Press.

Seitner, Philip.G, George A. Livingston, Ann S. Williams. (1960). Biology Code of the Chemical-Biological

Coordination

Center.

Washington DC: National Academy of SciencesNational Research Council.

Silvia,M.(2011). Uji Daya hambat Madu Bunga Kopi Terhadap Bakteri Staphylococcus aureus.

Soemarno. (2000). Isolasi Dan Identifikasi Bakteri Klinik. Yogyakarta: Yogyakarta.

Sumarno. (2010). Uji Efektivitas Ekstrak Daun Binahong (Anredera Cordifolia (Ten.) Stennis) Sebagai Anti Mikroba Terhadap Pseudomonas aeruginosa Secara in Vitro.Malang: Universitas Brawijaya.

Suranto, A. (2007). Terapi Madu. Jakarta: Penebar Plus.

Thalib, N. (2011). Penelusuran Senyawa Aktif Antibakteri Daun Saga (Abrus precatorius L Terhadap Bakteri Staphylococcus aureusSecara Bioautografi. Universitas Surabaya.

Todar.(2012). Online Textbook of Bacteriology [online]. Diakses pada tanggal 04 Juni 2014, dari http://textbookofbacteriolog y.net/pseudomonas.html.

Utami, Prapti, Desty E. P.(2013). The Miracle of Herbs. Jakarta: Agro Media Pustaka.

Wikipedia.Id. Diakses pada Juni 2014 dari wikipedia.org/wiki/madu

Winarsih, et al. (2003). Bakteriologi Medik. Malang: Bayu Media Publishing.

Yolandari,F.G. (2011). Uji Daya Hambat Madu Sonokeling
Terhadap Bakteri Echerichia coli ETEC. 